\title{
THE EFFECT OF EGRULEG VERSUS RULEG AND TEACHER-CENTREDNESS VERSUS STUDENT-CENTREDNESS ON PUPIL GAIN AND SATISFACTION*
}

\author{
J. F. M. J. VAN HOUT \\ C. T. C. W. METTES \\ Centre of Educational Research and Development (CDO) \\ Twente University of Technology, Postbox 217, Enschede, Holland
}

\begin{abstract}
Concerning the course construction project "Engineering Design", a decision had to be made about the instructional procedures of the seminar stage of the course. In order to come to this decision in a more justifiable way an experiment was designed to compare four instructional procedures (viz. a teacher-centred egruleg-, a student-centred egruleg-, a teacher-centred ruleg-, and a student-centred ruleg procedure) on cognitive pupil gain and satisfaction. For testing the hypotheses an analysis of variance design was used. Twelve groups of ca. 20 students were divided into the four cells of a $2 \times 2$ factorial design with one completely nested factor.

The results of the experiment have shown that there are no differences between the procedures as to pupil gain and satisfaction. However, differences were found between the separate student groups (nested factor), irrespective of the instructional procedures. A plausible explanation seems to be the effect of interaction between instructional procedures, teachers and students.
\end{abstract}

\section{Introduction}

This experiment was started within the context of the course construction project "Engineering Design" at the Twente University of Technology, in order to come to decisions about the educational procedures on a more empirical basis.

Learning to solve technical problems in a methodological way is an essential objective of the course "Engineering Design". The purpose of the

\footnotetext{
* Translated from the Dutch by Mrs. Rommes-Ruyters.
} 
project was to operationalize this educational objective, to find an adequate design method and to construct and evaluate the course. For more detailed information about this project we refer to: Van Hout et al., 1972 Van Hout and Mettes 1973a; Van Hout and Mettes 1974; Van Hout et al., 1974.

\section{Theoretical Framework}

\section{DIMENSIONS IN DISCOVERY LEARNING}

So far the course "Engineering Design" has been, characterized by an almoșt exclusive use of the discovery method. Evaluation of this method seemed necessary, because the literature (e.g. Shulman and Keislar, 1966) gives cause for scepticism and a more differentiated approach of the discovery method. However, there are no clear statements to be found in the literature. The results of research, comparing discovery teaching with explanatory teaching, can hardly be interpreted for several reasons (Hermann, 1969). First of all, discovery learning is used in more than one sense. Sometimes discovery is the educational objective: students are trained not in the discovery of rules, but in the development of strategies for the discovery of rules.

Used in another sense discovery learning is an inductive instructional procedure for learning rules. Other aspects which make comparison difficult are: differences in instructional materials and problems, basic knowledge and degree of difficulty, instructional levels (e.g. concept learning or problem solving), intensity of tutoring, point of time at which the rule is presented, the maximum of time available, etc. Up to the present there is no theoretical framework for the interpretation of research results about discovery learning in which all these aspects are included. The result is that no clear directives can be derived from the literature which might help in making concrete decisions during the constructing stage of a course Because of this fact we decided to set up an experiment ourselves. In order to make such an experiment as useful as possible those aspects of discovery learning should be chosen which can be used in the course in question. Hermann mentions two aspects which came up quite often in the discussion about the construction of the course "Engineering Design".

The first aspect is the inductive-deductive dimension. This dimension is usually given concrete form in the egruleg method (example-rule-example) versus the muleg method (rule-example). The other aspect which is often ascribed to the discovery method, is the self-reliance and initiative of the student during the learning process: the student has to discover by himself, he should make his own plan of action and has to take the initiative. This can be called student-centredness and it can be considered as one extreme of 
a continuum, the other extreme of which is teacher-centredness. This continuum is often only partially combined with the inductive-deductive dimension and in such a way that deductive-teacher-centred and inductive-studentcentred are considered to form an imperative combination. The combinations deductive-student-centred and inductive-teacher-centred, however, are possibilities which have hardly if ever been investigated.

\section{OPERATIONALIZATION}

egruleg the student starts with an example, from which he has to derive the rule; then an explanation of this rule and finally examples of applications of this rule are given;

ruleg here an explanation of the rule is the starting-point and examples of applications of this rule follow;

student- the student determines his own working pace and, if necessary, he centred can also take the initiative when he wants further explanations or a follow-up discussion with the teacher and/or other students.

teacher the teacher determines a collective working pace for all students centred and, if necessary, he can also take the initiative for explanations to or follow-up discussions with one or more students.

Those four variants can be combined into four instructional procedures, viz.:

I: egruleg + teacher-centred

II: ruleg + teacher-centred

III: egruleg + student-centred

IV: ruleg + student-centred

\section{HYPOTHESES}

The hypotheses were formulated as follows. There are no differences in cognitive pupil gain and in satisfaction of the students between:

1 the teacher-centred method and the student-centred method;

2 the egruleg method and the ruleg method;

3. the four instructional procedures which have been derived from the combination of the two dimensions.

\section{Experimental Design}

In planning the experiment we tried to choose only those instructional 
procedures which suit the course. In this way the relevance of the results was augmented, while the alternatives with regard to the experimental design were limited. We shall mention the most important characteristics of the design below. For more information we refer to Van Hout and Mettes (1973b). The experimental design was as follows:

\begin{tabular}{llllllll}
\hline & egruleg & & \multicolumn{5}{c}{ ruleg } \\
\hline $\begin{array}{lllllll}- \text { teacher- } \\
\text {-centred }\end{array}$ & $\begin{array}{l}\text { teacher } \\
\text { group }\end{array}$ & I & 2 & 3 & 4 & 5 & 6 \\
\hline student- & teacher & 7 & 8 & 9 & 10 & 11 & 12 \\
-centred & group & VII & VIII & IX & X & XI & XII \\
\hline
\end{tabular}

Figure 1: design of the experiment

For every cell in this figure three groups of about 20 students each were formed. This makes a total of 235 students involved in the project. Each group had one teacher. In terms of an analysis of variance this figure can be taken as a $2 \times 2$ factorial design with 1 completely nested factor (Dayton, 1970). A number of intervening variables seemed important. One of them is the comparability of the groups of students. From a statistical analysis of a number of personality- and intelligence tests which were administered at the beginning of the session it appeared that the separate groups, as well as the cells (combinations of three groups) did not differ significantly from each other in tested skills and personal characteristics. The influence of differences between the teachers has been checked statistically, as a nested factor in the analysis of variance. As the available time may also have a certain influence, a maximum period of three hours was fixed. In order to be able to check the comparability afterwards and to explain the results more effectively, the seminar was recorded on videotapes in all groups. The experiment was made in seminar 4 of the course Engineering Design 1971/1972. The objectives of that seminar were:

1. to acquire knowledge of and insight in a number of criteria which apply to a problem definition;

2. to use these criteria, i.e. to be able to make a problem definition which conforms with these criteria.

A discovery task, a chapter from the Design Manual and a few exercises were used as instructional materials. Two tests were administered: a pre-test and a post-test. The post-test consisted of 3 parts: 
- a multiple-choice test on knowledge of the criteria;

- an insight and application test, in which a problem had to be defined;

- a transfer-test, in which a problem definition was not asked for explicitly.

Finally, at the end of the seminar a questionnaire was given to to the students, in which questions were asked about how instructive, fascinating, clear and fluent they thought the seminar had been. For this purpose 5-point rating scales were used.

\section{Results}

After observations of the seminars recorded on videotape it appeared that on the whole all groups had worked according to the planned procedure. From the pre-test it appeared that the students did not have any knowledge of and insight in the definition of design problems whatsoever at the beginning of the seminar. This applied to all the groups. The post-test produced the following results: the 3 subtests together had a maximum score of 17 . The mean score of all 12 groups was 12.4 with a standard deviation of 2.67. The reliability expressed in the KR 20 (Kuder-Richardson) was 0.62 , which means that the test was moderately reliable.

From the results which have been described in Table $I$ it appears that there is no significant difference in pupil gain between students instructed according to the egruleg-ruleg method, the teacher-centred method or the combinations of those methods. This means that there is no reason to reject the null-hypotheses. There is a significant difference, however, between the 12 groups with their teachers, irrespective of the instructional procedure which was used (= the nested factor).

\section{TABLE I}

Analysis of variance of the results of the post-test.

\begin{tabular}{lrrrrr}
\hline & SS & df & MS & F & $\mathrm{p}^{*}$ \\
\hline 1. teacher- vs student-centred & 105.60 & 1 & 105.60 & 2.58 & 0.13 \\
2. egruleg vs ruleg & 0.20 & 1 & 0.20 & 0.005 & 0.94 \\
3. teacher-egruleg vs teacher-ruleg vs & & & & & \\
$\quad$ student-egruleg vs student-ruleg & 42.38 & 1 & 42.38 & 1.036 & 0.33 \\
4. groups and teachers & 449.78 & 11 & 40.89 & 8.43 & 0.0001 \\
5. within error & 1067.03 & 220 & 4.85 & & \\
6. total & 1664.99 & 234 & 7.17 & & \\
\hline
\end{tabular}

* level of significance $p<0.05$ 
From the results of the questionnaire it appears that the students thought the course instructive, clear, fluent and fascinating. From the analysis of variance of these data the same results emerge as from the analysis of variance of the cognitive pupil gain (see Table II): here again only the nested factor (=groups and teacher) is significant.

\section{TABLE II}

Analysis of variance of the satisfaction data

\begin{tabular}{lrrrrr} 
& SS & df & MS & F & p* \\
\hline 1. teacher- vs student-centred & 0.66 & 1 & 0.66 & 0.03 & 0.86 \\
2. egruleg vs ruleg & 17.33 & 1 & 17.33 & 0.81 & 0.61 \\
3. teacher-egruleg vs teacher-ruleg vs & & & & & \\
$\quad$ student-egruleg vs student-ruleg & 74.02 & 1 & 74.02 & 3.47 & 0.09 \\
4. groups and teacher & 234.82 & 11 & 21.35 & 2.29 & 0.01 \\
5. within error & 2051.48 & 220 & 9.32 & & \\
6. total & 2378.31 & 234 & 10.16 & &
\end{tabular}

* level of significance $p<0.05$

In order to find out which groups differed from each other Duncan's "multiple range test" has been used. Significant differences appeared mainly to exist between the several teacher-centred groups. The student-centred groups did not differ significantly from each other. This result applied to the pupil gain as well as to the satisfaction data.

\section{Conclusions}

Supposing the objectives and contents of this seminar are representative of the seminar stage of the course, the conclusion might be made that it does not make any difference to the cognitive pupil gain of the seminar stage of the course, nor to the satisfaction of the students, which of the four instructional procedures are used. At this point one restriction should be made: there are no data about the effects of these instructional procedures when used for a longer period of time, e.g. two months. Variation seems to be the best principle in this case (Rosenshine, 1971). However, the make-up of the groups themselves does seem to have an important influence on the results, whereas the groups do not differ on the tests administered beforehand and on the pre-test.

Therefore it seems plausible to try to find an explanation in he direction of interaction effects between instructional procedures, teachers 
and students. With regard to the relation teacher - instructional procedure we might suggest that a certain teacher might be more suited to, or might enjoy a certain instructional procedure more than another one.

In the context of this project it appeared that a number of teachers thought the student-centred method less suited to their own capacities, because their role was too passive and they had no idea of the progress of a great number of students. Training the teachers might be a good way to remove the imperfections found.

With regard to the relation student-instruction it can be assumed that one student will gain better results with a certain instructional procedure than another student, because this instructional procedure gives him better links with e.g. his way of thinking of studying. Skills which are important for successful discovery learning turn out to be less important for successful explanatory learning (Egan and Greeno, 1973).

\section{References}

Dayton, C. M. (1970). The Design of Educational Experiments. New York: McGraw-Hill. Egan, D. E. and Greeno, J. G. (1973). "Acquiring cognitive structure by discovery and rule learning," Journ. Educ. Psych. 64, 1:85-97.

Hermann, G. (1969): "Learning by discovery: a critical review of studies," Journ. exp. Educ., 38, 1: 58-72.

Hout, J. F. M. J. van, and Mettes, C. T. C. W. (1973a). "Onderwijs in het leren oplossen van technische problemen," in Woerden, W. van et al., Onderwijs in de maak. Utrecht: Spectrum.

Hout, J. F. M. J. van, and Mettes, C. T. C. W. (1973b). "Vier soorten onderwijsprocedures: een vergelijkend onderzoek," Wetenschaps Bulletin, November. Enschede: Twente University of Technology.

Hout, J. F. M. J. van, and Mettes, C. T. C. W. (1974). "The course development project "Engineering Design" at the Twente University of of Technology: Some aspects of planned change in higher education," in: Verreck, W. ed., Methodological Problems in Research and Development in Higher Education. Amsterdam: Swets and Zeitlinger.

Hout, J. F. M. J. van, Mettes, C. T. C. W. and Schultheiss, H. (1974). Het onderwijsontwikkelingsprojekt Technisch Ontwerpen. CERD report 26. Enschede: Twente University of Technology.

Hout, J. F. M. J. van, Schultheiss, H. and Mettes, C. T. C. W. (1972). Het onderwijsontwikkelingsprojekt Ontwerpen I 1970/1971: an interim report. CERD report 17, Enschede: Twente University of technology.

Rosenshine, B. (1971). Teaching Behaviours and Student Achievement. Windsor, Berks.: National Foundation for Educational Research in England and Wales.

Schulman, L.,S. and Keislar, E. R. eds. (1966). Learning by Discovery: a Critical Appraisal. Chicago: Rand-McNally. 